\section{Journal of \\ Epilepsy and \\ Clinical \\ Neurophysiology}

JEpilepsy Clin Neurophysiol 2012;18(1):12-15

\title{
Challenges in the Surgical Treatment of Epilepsy: Hypothalamic Hamartoma in Infancy - Case report
}

\author{
Larissa Alessandra Mehla, Paulo Breno Noronha Liberalesso ${ }^{\mathrm{b}}$, Mônica Jaques Spinosa ${ }^{\mathrm{a}}$, \\ Sílvio Machado ${ }^{\mathrm{a}}$, Alfredo Löhr Júnior ${ }^{\mathrm{a}}$ \\ Departamento de Neuropediatria do Hospital Pequeno Príncipe, Curitiba, PR, Brasil
}

\begin{abstract}
Introduction: Hypothalamic hamartoma is a rare congenital malformation, characterized by epilepsy, especially gelastic seizures, psychomotor developmental delay, mental retardation, behavioral disorders and precocious puberty. Epilepsy has early onset and is usually medically refractory. Etiology and pathophysiological mechanisms are unclear. The EEG can present disorganization and slowing of background activity and multifocal and/ or generalized epileptogenic discharges. Objective: To report the difficulties and challenges of neurosurgical treatment of a hypothalamic hamartoma in an infant. Case report: Infant with seizures since eight months old of age. The neurological investigation revealed a lesion in tuber cinereum suggestive of hamartoma. The epilepsy evolved with resistance to antiepileptic drugs, requiring neurosurgical procedure. The endoscopic resection could not be performed because the hamartoma was firmly attached to the hypothalamus. Currently, the child remains with tonic, clonic and atonic seizures. Discussion: Lesionectomy performed by microsurgery or radiosurgery seems to be the most effective treatment for seizure control in patients with hypothalamic hamartomas who do not respond to clinical treatment. Callosotomy may be effective in selected cases, and lobectomy/cortical resections are not related to seizure control. In some patients, particularly in infants, lesionectomy and radiosurgery may be technically unfeasible.
\end{abstract}

Keywords: Hypothalamic hamartoma; gelastic seizures; epilepsy.

\section{RESUMO}

Desafios no tratamento cirúrgico das epilepsias: hamartoma hipotalâmico na infância - relato de caso Introdução: hamartoma hipotalâmico é uma malformação congênita rara, que pode se manifestar através de crises epilépticas, principalmente as gelásticas, atraso do desenvolvimento neuropsicomotor, retardo mental, distúrbios comportamentais e puberdade precoce. As crises têm início precoce e são clinicamente refratárias. A etiologia e os mecanismos fisiopatogênicos não são totalmente conhecidos. O eletrencefalograma pode apresentar desde desorganização e alentecimento da atividade de base até paroxismos epileptogênicos multifocais e/ou generalizados. Objetivo: relatar as dificuldades e desafios do tratamento neurocirúrgico em um caso de hamartoma hipotalâmico em um lactente. Relato do caso: lactente com crises epilépticas desde oito meses de idade. A investigação revelou a presença de uma lesão em túber cinerium sugestiva de hamartoma. As crises tornaram-se refratárias, sendo indicado procedimento cirúrgico. A ressecção endoscópica não pôde ser realizada, pois o hamartoma encontrava-se totalmente aderido ao hipotálamo. Atualmente, a criança mantém crises tônicas, clônicas e atônicas. Discussão: a lesionectomia realizada por microcirurgia ou radiocirurgia parece ser o tratamento mais efetivo para o controle das crises em pacientes com hamartoma hipotalâmico. Calosotomia pode ser eficaz em casos selecionados e lobectomias/ressecções corticais não tem efetividade no controle das crises. Em alguns pacientes, particularmente nos lactentes, lesionectomia e radiocirurgia podem ser tecnicamente inviáveis. Quando o tratamento neurocirúrgico não é possível a epilepsia deve ser classificada como intratável.

Unitermos: hamartoma hipotalâmico; crise gelástica; epilepsia.

a Department of Neuropediatrics, Hospital Pequeno Príncipe, Brazil.

b Department of Neuropediatrics, Hospital Pequeno Príncipe, Brazil. University Tuiuti of Paraná, Otoneurology Research Center, Brazil. Received Jan. 10, 2012; accepted Feb. 01, 2012. 


\section{INTRODUCTION}

Although in most people with epilepsy it is possible to obtain satisfactory control of seizures with antiepileptic drugs in mono or polytherapy, 20 to $30 \%$ of these patients will remain with recurrent seizures despite treatment.

Hamartoma is a word of Greek origin, derived from hamartion, which means "failure of the body". ${ }^{1}$ The hypothalamic hamartomas $(\mathrm{HH})$ are rare congenital malformations of unknown etiology that arise between the sixth and seventh weeks of pregnancy, characterized as non-neoplastic lesions located in the tuber cinereum. The $\mathrm{HH}$ can cause serious neurological problems such as epileptic encephalopathy, psychomotor developmental delay, mental retardation and precocious puberty. 2,3

Gelastic seizures are the most frequently observed seizure type in children with $\mathrm{HH}$, although clonic, tonic, tonic-clonic, spasms and atypical absences may also occur. Seizures of laughter can also occur in symptomatic focal epilepsies originating in the frontal and temporal lobes and are characterized by episodes of stereotyped, paroxysmal and inappropriate laughter. ${ }^{4}$

Although the term "gelastic seizure" has been introduced by Daly and Mulder (1957), it Trousseau (1873) was who suggested that episodes of uncontrollable laughter could represent an epileptic phenomenon. In infants, gelastic seizures are less frequent, with predominance of seizures with axo-rhizomelic motor component. ${ }^{5}$

Some patients, who do not have their seizures controlled with antiepileptic drugs, may benefit from surgical procedures. Successful neurosurgical resection of $\mathrm{HH}$ can result in complete control of seizures, improved of behavior, motor development, language and cognitive ability.

The aim of this article is to present the diagnostic and therapeutic difficulties in a pediatric case of epileptic encephalopathy secondary to hamartoma in the tuber cinerium. The study was approved by the Ethics and Human Research Committee of Hospital Pequeno Príncipe (registration number: 921-11).

\section{CASE REPORT}

Female patient, two years and six months old, born by cesarean delivery, term (39 weeks gestational age). Pregnancy and birth occurred without clinical or surgical complications.

At eight months of age the patient began with epileptic seizures characterized by sudden vocal emission, followed by forced opening of the eyes, staring, generalized reduction of muscle tone, facial pallor, lip cyanosis, with an estimated duration of a few seconds. Initially the events were more frequent during sleep.
After the first year, seizure semiology changed, with increased muscle tone of the limbs (arms with flexed tonic posture and legs with extended tonic posture), upper deviation of the eyes, repetitive blinks, facial pallor and lip cyanosis, occurring mainly during wakefulness. The seizures remained short lasting, but occurring several times a day. At twelve months of life the psychomotor development was severely compromised. A family history of seizures or specific epileptic syndromes was not identified.

Subsidiary investigation revealed normal evoked auditory brainstem response and normal ophthalmologic examination with fundoscopy. The EEG performed at ten months of age revealed high amplitude slow waves, generalized and multifocal discharges of various morphologies (including sharp wave, spike, polispike, spike-wave and polispike-wave), fast generalized discharges (tonic pattern) and segments of hypsarrhythmia. The videoEEG (24 hours) showed several episodes of tonic seizures during sleep. Magnetic resonance imaging (MRI) revealed a solid nodular lesion, hyperintense on T2-weighted sequences, on the floor of the third ventricle, suggestive of a hamartoma of the tuber cinereum. Precocious puberty was investigated with pelvic ultrasound, X-rays of left wrist and hand, and hormone levels of FSH, LH and prolactin (all normal).

After failure of medical treatment with antiepileptic drugs (phenobarbital, sodium valproate, clonazepam and vigabatrin), the patient was referred to neurosurgical treatment. At two years and three months of age, the patient underwent endoscopic resection of the hamartoma. The surgery was unsuccessful, since the hamartoma was fully adhered to the hypothalamus.

At two years and six months, the patient has daily seizures (tonic, clonic, and atonic), and regression of the perceptual-motor development, with poor visual contact.

\section{DISCUSSION}

Hamartoma of the tuber cinereum is a relatively rare malformation of the developing central nervous system. Between 1934 and 1963 only 30 cases had been reported and about one hundred cases until the 1980s. The prevalence is estimated at 1 per 200,000 live births, with a predominance in males, without familial incidence or racial predominance. Disease gravity is highly variable, ranging from asymptomatic or oligossintomatic presentations to catastrophic neurological presentations..$^{1,5,6}$

The exact sequence of events during the embryonic period that leads to the formation of a $\mathrm{HH}$ is not entirely clear. It is believed that the appearance of $\mathrm{HH}$ occurs between the fifth and sixth weeks gestational age. 


\section{Clinical aspects}

Although gelastic seizures may occur in other circumstances, they are recognized as being strongly suggestive of a hamartoma in tuber cinereum. In the first two years of life these seizures may be uncharacteristic and may be preceded by many years other types of seizures with more exuberant motor manifestations. Some researchers believe that these ictal events that arise later may result from the classical phenomena of secondary epileptogenesis $^{7}$. These epileptic seizures are often classified as medically refractor. Although seizures have varied clinical manifestations in infancy and childhood in patients with $\mathrm{HH}$, delayed motor development and cognitive impairment are the rule.

A clinical study of patients with $\mathrm{HH}$ showed that all had seizures, 49\% developed cognitive impairment and 31\% manifested behavioral disturbances. Behavioral disorders varied in severity, including psychomotor agitation, episodes of violence, emotional instability, autistic features, obsessive and antisocial behavior. ${ }^{8}$ On the other hand, severe behavioral disturbances reported in the literature are rarely seen in children below 2 years of age.

The hypothalamic-pituitary axis maintains anatomical and functional relationship with the limbic system. During early childhood, autonomic signs as changes in blood pressure, tachycardia, cyanosis, pallor and sweating may occur as a result of epileptic phenomena or non-epileptic phenomena. Autonomic manifestations may occur by changes in the limbic system, the adrenergic system and the hypothalamic-pituitary axis. ${ }^{9}$ Nonspecific clinical manifestations often delay the diagnosis of hamartoma of cinerium tuber in infants.

Polymorphism of seizures (tonic, clonic, and atonic) and unsatisfactory response to antiepileptic drugs are common in patients with $\mathrm{HH}$. Our patient had early onset of seizures suggesting worse neurological prognosis.

Early puberty is considered relatively common in children with hypothalamic lesions, can be defined as the appearance of secondary sexual characteristics before age eight in females and before age nine in males. Precocious puberty due to the increase in the secretion of hypothalamic gonadotropin-releasing hormone $(\mathrm{GnRH})$, resulting in changing the hormonal hypothalamus-pituitary-gonads axis. The main signs of precocious puberty in girls are the appearance of the breasts, pubic and underarm hair, accelerated growth and oily skin. In boys, it is characterized by testicular growth, pubic hair, underarm odor, episodes of aggression, acne, and change of voice tone.

Although our patient has not shown signs of precocious puberty, we performed a preliminary investigation by the dosage of FSH, LH and prolactin, $\mathrm{X}$-rays of hand and wrist and pelvic ultrasound which proved normal.

\section{Electroencephalographic aspects}

Interictal changes observed in epilepsy associated with $\mathrm{HH}$ are nonspecific and can range from slowing and disorganization of background activity to frequent discharges of high voltage and varied morphologies. The epileptogenic paroxysms may be generalized or multifocal (epileptic discharges in more than three independent cortical topographies).

The exact pathophysiological mechanisms by which these hamartomas generate interictal discharges and focal or generalized seizures themselves are not clear. A study using electrocorticography in eight patients with $\mathrm{HH}$ demonstrated ictal onset zone in the anterior temporal lobe in seven cases and in the frontal lobe in one case. However, surgical resection of these cortical regions did not lead to seizure control, suggesting that the presence of hamartoma maintains a close relationship with the mechanisms generating epileptic events. ${ }^{10}$

In our patient, the first EEG was performed about two months after the onset of seizures, showing slowing and disorganization of background activity in hemispheres, polymorphic discharges, hypsarrhythmia. Rapid generalized discharges were also identified, suggesting a poor neurological prognosis. The video-EEG performed several months later showed tonic seizures during sleep. Although the electrographic findings are nonspecific, they are compatible with epileptic encephalopathy associated with hypothalamic hamartoma.

\section{Neuroimaging aspects}

MRI is the method of choice in suspected cases, showing a solid and not calcified lesion, with rounded morphology in the topography of the tuber cinereum. The image must be hypointense on T1-weighted sequences and iso or hyperintense on T2. The presence of calcifications, cysts or variations in signal intensity suggest neoplastic tumors. ${ }^{11}$

The brain MRI findings in our patient were consistent and strongly suggestive of $\mathrm{HH}$. In typical cases of hypothalamic hamartoma biopsy is often not performed.

\section{Neurosurgical aspects}

Probably the greatest challenge in neurosurgery patients with symptomatic epilepsies is to get access and resection of the lesion causing the least possible damage to healthy brain tissue. In epileptic patients with $\mathrm{HH}$, lesionectomy performed by microsurgery or radiosurgery seems to be the most effective treatment for seizure control. Callosotomy can be effective in selected cases when there is a predominance of tonic and/or atonic seizures, while cortical resections and lobectomies have no efficacy. ${ }^{12}$ 
Surgical procedures to treat hamartomas of tuber cinereum have been made since mid-1960. In a large series published by Cascino et al., ${ }^{10}$ the surgical procedures involved resection of hamartoma, callosotomy, resection cortical and occipital or temporal lobectomy. The best results were observed in the resection of the lesion. Callosotomy decreased the frequency of atonic events, but did not reduce the frequency of other types of seizures. None of the patients who underwent cortical resection and/or lobectomy experienced improvement in their epilepsy.

Fohlen et al. ${ }^{13}$ reported their surgical results in 18 patients, mean age 15 months, with medically refractory epilepsy secondary to $\mathrm{HH}$, showing that when performed by experienced medical staff, conventional surgery (lesionectomy) is relatively safe and can promote complete control of seizures in nearly half the cases.

As injury to important structures during the resection of $\mathrm{HH}$ is relatively common, less invasive alternatives have been developed. In the late 1990s, the first case of a patient with epilepsy secondary to a hypothalamic hamartoma who underwent radiosurgery was reported, with complete control of seizures ${ }^{2}$. Radiosurgery uses a spatial coordinate system intended to address injuries of difficult surgical access, using a high dose of radiation with extreme precision in targets with well-located and well-defined limits. The advantage of radiosurgery over conventional radiotherapy is the smaller irradiation of adjacent normal brain tissue. ${ }^{14}$ Cascino et al. ${ }^{10}$ reported complete control of seizures after radiofrequency thermocoagulation in two patients and reduced frequency and intensity of seizures in three of six cases treated with implantation of a vagal stimulator system.

In our patient, during the neurosurgical procedure it was verified that the hamartoma was firmly adhered to the anatomical structures of the hypothalamus-pituitary axis, making the resection of high risk for developing severe endocrine disorders. For this reason, the decision was made to abort the neurosurgical procedure. Because of the risks and technical difficulties to perform radiosurgery in a child of young age, it was chosen not to treat the lesion by this method.

\section{FINAL REMARKS}

Around 20 to $30 \%$ of children with epilepsy will not have satisfactory control of seizures with the use of antiepileptic drugs alone. For these patients, neurosurgery represents a therapeutic option. However, particularly for younger children, technical difficulties may impair the performance of neurosurgical procedures.

\section{REFERENCES}

1. Sharma RR, Silva RR. Hamartoma of the hypothalamus and tuber cinereum: a brief review of the literature. J Postgrad Med 1987;33:1-13.

2. Arita K, Ikawa F, Kurisu K, et al. The relationship between magnetic resonance imaging findings and clinical manifestations of hypothalamic hamartoma. J Neurosurg 1999;91:212-22

3. Ng Y, Rekate HL, Prenger EC, et al. Transcallosal resection of hypothalamic hamartoma for intractable epilepsy. Epilepsia 2006; 47:1192-202.

4. Loiseau P, Cohadon F, Cohadon S. Gelastic epilepsy: a review and report of five cases. Epilepsia 1971;12:313-23.

5. Daly DD, Mulder DW. Gelastic epilepsy. Neurology 1957;7:189-92.

6. Rosenfeld, JV. The evolution of treatment for hypothalamic hamartoma: a personal odyssey. Neurosurg Focus 2011;30(2):E1.

7. Berkovic SF, Arzimanoglou A, Kuzniedky R, et al. Hypothalamic hamartoma and seizures: a treatable epileptic encephalopathy. Epilepsia 2003;44:969-73.

8. Palmini A, Chandler C, Andermann F, et al. Resection of the lesion in patients with hypothalamic hamartomas and catastrophic epilepsy. Neurology 2002;58:1338-47.

9. Gordon N. Gelastic seizures. J Pediatr Neurol 2003;1(2):69-73.

10. Cascino GD, Andermann F, Berkovic SF. Gelastic seizures and hypothalamic hamartomas: evaluation of patients undergoing chronic intracranial EEG monitoring and outcome of surgical treatment. Neurology 1993; 43:747-50.

11. Saleem, SN, Said AM, Lee DH. Lesions of the Hypothalamus: MR Imaging Diagnostic Features. RadioGraphics 2007;27:1087-108.

12. Gomes MM. Epilepsia focal refratária: perspectivas terapêuticas. Rev bras Neurol 2005;41(2):37-43.

13. Fohlen M, Lellouch A, Delaland O. Hypothalamic hamartoma with refractory epilepsy: surgical procedures and result in 18 patients. Epileptic Disord 2003;5(4):267-73.

14. Mascarenhas F, Costa MS, Ortiz M, et al. A radiocirurgia estereotáxica em tumores benignos e malignos do sistema nervoso central. Acta Med Port 2005;18:45-60.

Corresponding Author

Paulo Breno Noronha Liberalesso

Department of Neuropediatrics, Hospital Pequeno Príncipe, Brazil

Rua Desembargador Motta, 1070

CEP 80250-060, Curitiba, PR, Brazil

Tel.: (+55-41)3310-1054-Fax: (+55-41)3310-1393

E-mail: <paulo.neuroped@gmail.com> 